To Cite This Article: Çoklar, A. N \& Bozyiğit, R. (2021). Determination of technology attitudes and technostress levels of geography teacher candidates. International Journal of Geography and Geography Education (IGGE), 44, 102-111.

\title{
DETERMINATION OF TECHNOLOGY ATTITUDES AND TECHNOSTRESS LEVELS OF GEOGRAPHY TEACHER CANDIDATES
}

\author{
Ahmet Naci ÇOKLAR ${ }^{1}$ \\ Recep BOZYiĞiT²
}

\begin{abstract}
With the effect of the global epidemic, the use of technology has increased more, and digital technologies have been used in all fields of life. One of these fields is education. Particularly, the attitudes towards technology and technostress levels of teacher candidates in Geography education, which is the department that undertakes the role of educator of tomorrow and where technology is partially used less, have been investigated. The aim of this study is to determine the technostress levels and attitudes towards technology of geography teacher candidates. The research is in survey model and an online questionnaire form was applied to 148 teacher candidates studying at Necmettin Erbakan and Marmara University Faculty of Education, Department of Geography Education for the 2020-2021 academic years. "Determining Teachers' Technostress Levels" and "Teacher Candidates' Attitudes towards Technology" scales were used as data collection tools. The internal consistency coefficients obtained in this study were calculated as .86 and .83 . As a result of the study, the attitudes towards technology and technostress levels of the geography teacher candidates were found to be medium level. The grade level and average daily internet usage time are important for technostress, but it does not make any difference according to the attitude towards technology. While gender is not an important variable for technostress, it is important in terms of attitude towards technology, men have more technology attitudes than women. There is a negative and low level relationship between attitude towards technology and technostress level. As a recommendation, It may also be suggested to provide geography teacher candidates with more applied training in order to gain an attitude towards technology and reduce their technostress'
\end{abstract}

Keywords: Technostress, Technology Attitude, Education, Geography Teacher Candidate, Covid-19

\footnotetext{
${ }^{1}$ Correspondence to: Prof.Dr., Necmettin Erbakan University, Ahmet Keleşoğlu Education Faculty, Computer Education and Instructional Technology Department, Meram, 42090, Konya, TURKEY., https://orcid.org/0000-0001-9210-4779., ahmetcoklar@hotmail.com

${ }^{2}$ Assoc.Prof.Dr., Necmettin Erbakan University, Ahmet Keleşoğlu Education Faculty, Department of Geography Education, Meram, 42090, Konya, TURKEY., https://orcid.org/0000-0002-9790-1168., rbozyigit@erbakan.edu.tr
} 


\section{INTRODUCTION}

Technology causes a rapid change in the field of education as in every field. Especially the rapid change experienced in recent years has reaffirmed the importance of the concept of technology integration. Technology integration in education, in its simplest form, is defined as using technology in learning processes to improve students' learning experiences (Bauer and Kenton, 2005), using technology to improve and support the educational environment (Ertmer, 2005) using technology tools in general content areas in education to enable students to apply their computer and technology skills to learning and problem solving (Kim et al., 2013). The definitions refer to the effective use of technologies to increase students' learning in educational environments. Although students are the target audience in technology use, teachers who direct the education process in the classroom have decisive roles in technology use. Technology can be included in educational environments as much as the teacher's teaching plan, his/her knowledge, competence, perception and attitude towards technology (Chen, 2008; Shattuck, 2010). Because as education planners in their classrooms, teachers have a decisive role in how and when to use which technology (Dalal, Archambault and Shelton, 2017).

Considering these roles of teachers, it is seen that education for this role has an important place in teacher training and professional development processes (Lawless and Pellegrino, 2007). Both teacher candidates and in-service teachers in education faculties receive important training on the use of technology (Şendurur and Arslan, 2017; Tatlı and Akbulut, 2017). With this training, teachers or teacher candidates gain skills in using technology. Although training is provided for non-digital materials within the scope of the educational content, the use of internet and digital technologies as the technology of the age, material design, production and selection has an important place (Chase and Laufenberg, 2011). On the other hand, especially with the recent Covid-19 global epidemic, the use of digital technologies has increased even more, and education stakeholders from all walks of life, from teachers to students, have been directed more towards the use of technologies (Marinoni et al., 2020). In this process, the distance education process caused teachers as well as students to enter a rapid adaptation process, and the integration of digital technologies into the education process has become increasingly important.

Despite the advantages that technology provides due to its nature, it also requires an adaptation process. The Technology Acceptance Model (TAM) developed by Davis (1989) can be expressed as an important theory in terms of shedding light on the general perspective of teachers' use. Davis (1989) in the TAM theory emphasizes psychological factors to explain the behavior of the use of technology. Accordingly, attitudes are among the factors that affect behavior intention, such as fitness or compliance, perceived usefulness, perceived ease of use (King and He, 2006). Another theory is Planned Behavior Theory (PBT), and according to this theory, there are some factors that include the use of technology and shape social behaviors, and these behaviors must have a purpose in order to turn them into action (Ajzen, 1991). There are important elements in planned behavior theory such as attitude towards behavior, subjective norms and perceived behavior control (Erten, 2002). According to this theory, many intermediate variables such as social pressure, attitude, motivation, experience, opportunities that affect behavior affect the formation of behavior (Mercan, 2015). In this context, the concepts of technostress and attitude towards technology, which include both social and psychological pressures of teacher candidates, were considered important and determined as a research topic.

The concept of technostress is expressed as a type of stress (Brod, 1984). Weil and Rosen (1997) defined technostress as a negative effect on the behaviors, attitudes, thoughts and psychology of individuals due to the use of technology. While Champion (1988) defined technostress as the price paid for the use of technology, Brod (1984) expressed it as the negative pressure that rapidly developing technologies cause on human life. Wang, Shu, and Tu (2008), on the other hand, define technostress as the pressure of other people or responsibilities on the use of technology in individuals as a result of the gaining importance of technology use skills in work environments. Brillhart (2004) in his definition starting from the employees, planning of business meetings, follow-up work and a lot of digital content technologies as stated cause teknostres on employees in establishments such as the rush of them. In general, technostress can be defined as a type of psychological disorder caused by the pressure to use technology.

Another issue addressed within the scope of the research was the attitude towards technology. Attitude is defined as the readiness or disposition of individuals to accept or reject an institution, person, fact, or idea (Topsakal, 2006). Similarly, Çetin (2012) defines attitude as a tendency that guides an individual's ideas, objects, events or thoughts, feelings and behaviors towards other people, and states that the individual can psychologically develop an attitude towards everything such as things, ideas, events, and institutions. Attitudes have functions such as adaptation, utility, creating value judgments, providing information and directing behaviors (Eagly and Chaiken, 1998). In this respect, it can be said that attitude has an important effect on behavior. Technology is one of the facts that can be improved attitude. It is defined by Agar (2020) as using tools to achieve a goal, including techniques and processes obtained as a 
result of scientific knowledge. In this respect, the dimension of equipment and technology is a concept that includes all kinds of machines, especially mobile phones, computers, and it is a broad concept that includes not only tools and equipment, but also the experiences, application methods and processes that have been developed for their use (McCarthy and Wright, 2004). Today, although the concept of technology is expressed as technologies such as computers, mobile devices and the internet, it should be emphasized that it includes much more. Attitude towards technology is defined as "the readiness or disposition of individuals to accept or reject the use of today's technologies", taking into account the definition of attitude made by Topsakal (2006). It is stated that the positive or negative attitudes of teachers towards technology is one of the important variables in fulfilling their teaching duties (Şahin and Namlı, 2019; Özdemir and İmra, 2017).

The research was conducted within the global Covid-19 global epidemic process. For this reason, teacher candidates, as individuals in the educational process, have also been under pressure to use technology. Determination of the technostress levels of the teacher candidates and their attitudes towards technology makes the research important in this process where the use of technology is felt intensively in all areas of life, especially in education. On the other hand, conducting the research with geography teacher candidates can be expressed as the importance of the research. Demirci et al. (2007) examined the classes in which geography lessons were given, and stated that these classes were less inadequate in terms of technological equipment compared to other classes. Demirci et al. (2007) attributed this situation to the inadequacy of geography teachers' skills in using technology, and suggested that technology education should be given more effectively to teachers and prospective geography teachers studying at education faculties. In another study, it was stated that the technology knowledge of geography teachers was not sufficient, and it was emphasized that the inability of geography teachers to keep up with the technological development speed was the effect of this issue (Doğru and Aydın, 2018). Şahin and Namlı (2019) stated that in departments where technology use is more intense, the attitude towards technology use will be higher. Menzi et al. (2012) stated in their study with prospective teachers that the technology proficiency of the verbal department students was lower than the numerical departments. In this respect, the investigation of geography teachers' technostress levels and their attitudes towards technology as a psychological factor in technology integration makes the study important.

Purpose of the Research

The aim of this study is to determine the technostress levels and attitudes towards technology of geography teacher candidates. For this purpose, answers to the following questions were sought;

1. What are the technostress levels and attitudes towards technology of prospective geography teachers?

2. Does technostress levels and their attitudes towards technology of prospective geography teachers differ according to

a. grade level

b. average daily internet usage time

c. gender variables?

3. What is the relationship between the technostress levels and attitudes towards technology of prospective geography teachers?

\section{METHOD}

In this section, information about the research model, participants, data collection tools and data analysis is given.

\section{Research Model}

The research is a quantitative research, and it is a survey model that includes both singular and relational survey models. Survey models are used to reveal the views, attitudes or behaviors of individuals in a population or a representative sample of a subject (Creswell, 2012). While the singular survey model refers to the research models made to determine the variables one by one, type or quantity, the relational survey model is the research model that aims to determine whether there is a change between two or more variables and the degree of change (Karasar, 2012).

\section{Population and Sample}

The universe of the research consists of the prospective teachers studying at the Faculty of Education, the Department of Turkish and Social Sciences Education, and the Department of Geography Education in the 2020-2021 academic years. There are students of related departments in 8 different universities in Turkey. In this context, data were 
collected from geography teacher candidates studying at Konya Necmettin Erbakan University, Ahmet Keleşoğlu Faculty of Education and Istanbul Marmara University, Atatürk Faculty of Education. Since the research population can be reached and data can be collected from the entire population, no sample was taken. There are approximately 200 students studying in total. An online survey (data collection form) was developed to collect research data. During March 2021, a link was shared with prospective teachers at both universities and they were asked to be filled on a voluntary basis.

\begin{tabular}{|c|c|c|c|}
\hline \multicolumn{4}{|c|}{ Table 1: Demographic Information of Participants $(n=148)$} \\
\hline Variables & & f & $\%$ \\
\hline Gender & $\begin{array}{l}\text { Female } \\
\text { Male }\end{array}$ & $\begin{array}{l}79 \\
69 \\
\end{array}$ & $\begin{array}{l}53,4 \\
46,6\end{array}$ \\
\hline Grade levels & $\begin{array}{l}1^{\text {st }} \text { grade } \\
2^{\text {nd }} \text { grade } \\
3^{\text {rd }} \text { grade } \\
4^{\text {th }} \text { grade }\end{array}$ & $\begin{array}{l}31 \\
40 \\
32 \\
45 \\
\end{array}$ & $\begin{array}{l}20,9 \\
27,0 \\
21,6 \\
30,4\end{array}$ \\
\hline Computer or Tablet ownership & $\begin{array}{l}\text { Yes } \\
\text { No }\end{array}$ & $\begin{array}{c}134 \\
32 \\
\end{array}$ & $\begin{array}{l}90,5 \\
21,6 \\
\end{array}$ \\
\hline Average daily internet usage & $\begin{array}{l}1 \text { hour or less per day } \\
\text { Between 2-4 hours a day } \\
\text { More than } 5 \text { hours a day }\end{array}$ & $\begin{array}{l}40 \\
76 \\
32 \\
\end{array}$ & $\begin{array}{l}27,0 \\
51,4 \\
21,6 \\
\end{array}$ \\
\hline Total & & 148 & 100 \\
\hline
\end{tabular}

When Table 1 is examined, it can be seen that $53 \%$ of the participants are female and $46 \%$ are male, according to the classes, $1^{\text {st }}$ graders are represented by $20 \%, 2^{\text {nd }}$ graders $27 \%, 3^{\text {rd }}$ graders $21 \%$ and $4^{\text {th }}$ graders $30 \%$ respectively. On the other hand, it can be said that the majority (90\%) have their own tablet or computer and mostly (73\%) use the internet for 2 hours or more per day.

\section{Data Collection Tool}

In addition to the personal information form, attitude towards technology scale and the scale for determining teachers' technostress levels were used as data collection tools. In order to determine the technostress levels of teacher candidates, the Determining Teachers' Technostress Levels Scale of developed by Çoklar, Efilti and Şahin (2017) was used. The related scale consists of 28 items and 5 factors. The internal consistency coefficient (Cronbach's alpha coefficient) of the factors that make up the scale takes values between .712 and .788. The internal consistency coefficient obtained in this study for technostress scale was calculated as .86. In order to determine their attitudes towards technology, the Scale of Teacher Candidates' Attitudes towards Technology developed by Aydın and Kara (2013) was used. The scale, with the participation of 378 teacher candidates, has a single factor structure and consists of 17 items, 15 of which are positive. The reliability coefficient of the scale is expressed as $\alpha=0.87$. In this research, the consistency coefficient of technology attitude scale was calculated as .83 .

\section{Data Analysis}

In the scoring of the attitude scale and the technostress scale, scoring was made as "1-I do not agree at all ... 5-I completely agree". Negative items in the attitude scale were scored in reverse. Percentage and frequency were used in the analysis of descriptive data, while arithmetic mean and standard deviation values were used to determine geography teacher candidates' attitudes towards technology and technostress levels. Independent sample t-test was used to determine the difference between geography teacher candidates' attitudes towards technology and technostress levels according to gender, and one-way analysis of variance (ANOVA) was used to determine the differences according to the grade level and daily average internet usage time. Finally, pearson moments product correlation coefficient was used to determine the relationship between attitude towards technology and technostress level. The data were made with an analysis program and the level of significance was accepted as .05.

For the interpretation of the data on the technostress levels of the geography teacher candidates and their attitudes towards technology, three evaluation criteria were adopted as low, medium and high based on their average scores. Accordingly, the formula of the highest score - the lowest score / criteria number and the following value range and evaluation criteria were used to interpret the averages (Table 2).

\begin{tabular}{|c|c|}
\hline \multicolumn{2}{|c|}{ Table 2: The Range and Criteria for Evaluating The Technostress Levels and Attitudes } \\
\hline Evaluation Range & Evaluation Criteria \\
\hline $1.00-2.33$ & Low \\
\hline $2.34-3.66$ & Medium \\
\hline $3.67-5.00$ & High \\
\hline
\end{tabular}




\section{FINDINGS AND COMMENTS}

The findings obtained within the scope of the research are given below.

\section{Attitudes towards Technology and Technostress Levels of Geography Teacher Candidates}

Within the scope of the research, the attitudes towards technology and technostress levels of 148 geography teacher candidates who participated in the research are calculated and given in Table 3.

\begin{tabular}{|c|c|c|c|}
\hline & $\overline{\mathbf{X}}$ & ss & Level \\
\hline Technology Attitudes & 3,63 & ,518 & Medium level \\
\hline Technostress Levels & 3,44 & ,707 & Medium level \\
\hline Learning - Teaching Process Oriented & 3,14 & ,849 & Medium level \\
\hline Profession Oriented & 2,89 & ,900 & Medium level \\
\hline Technical Issue Oriented & 4,01 & 819 & High level \\
\hline Personal Oriented & 3,43 & ,879 & Medium level \\
\hline Social Oriented & 3,93 & 829 & High level \\
\hline
\end{tabular}

When Table 3 is examined, it can be seen that the geography teacher candidates' attitudes towards technology are medium level $(X=3,63)$. Similarly, technostress levels are medium level $(X=3,44)$. When examined in terms of the subdimensions of the technostress scale, while the geography teacher candidates experience high levels of technostress in technical issue oriented $(X=4,01)$ and social oriented $(X=3,93)$ subjects, they experience medium level technostress in other dimensions, learning-teacher process oriented $(X=3,14)$, profession oriented $(X=2,89)$ and personal oriented $(X=3,43)$ subjects (Table 3$)$.

\section{Geography Teacher Candidates' Attitudes towards Technology and Technostress Levels by Grade Level}

Within the scope of the study, it was determined whether the attitudes towards technology and technostress levels of geography teacher candidates differ according to their grade levels. The results obtained are shown in Table 4.

\begin{tabular}{|c|c|c|c|c|c|c|c|c|c|c|c|}
\hline & $\begin{array}{l}\text { Grade } \\
\text { Levels }\end{array}$ & $\mathbf{n}$ & $\bar{X}$ & sd & Source of Variance & Sum of Squares & df & Mean Square & $\mathbf{F}$ & $\mathbf{p}$ & Differences \\
\hline \multirow{4}{*}{ 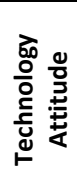 } & $1^{\text {st }}$ grade & 31 & 3,64 & ,422 & Between Groups & 1,028 & 3 & ,343 & \multirow{2}{*}{1,282} & \multirow[t]{2}{*}{283} & \multirow{3}{*}{-} \\
\hline & $2^{\text {nd }}$ grade & 40 & 3,67 & ,511 & Within Groups & 38,481 & 144 & ,267 & & & \\
\hline & $3^{\text {rd }}$ grade & 32 & 3,48 & ,700 & Total & 39,509 & 147 & & & & \\
\hline & $4^{\text {th }}$ grade & 45 & 3,70 & ,418 & & & & & & & \\
\hline \multirow{4}{*}{ 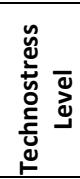 } & 1. grade & 31 & 3,73 & 618 & Between Groups & 5,131 & 3 & 1,710 & 3,603 & ,015* & \multirow{3}{*}{$1-4$} \\
\hline & 2. grade & 40 & 3,45 & 748 & Within Groups & 68,353 & 144 & ,475 & & & \\
\hline & 3. grade & 32 & 3,46 & 819 & Total & 73,484 & 147 & & & & \\
\hline & 4. grade & 45 & 3,21 & ,568 & & & & & & & \\
\hline \multicolumn{12}{|c|}{$* p<.05$} \\
\hline
\end{tabular}

As can be seen from Table 4, the attitudes of geography teacher candidates towards technology do not differ according to their grade $\left(F_{(3-144)}=1.282, p>.05\right)$. In other words, it can be said that their attitudes towards technology are the same in every period of education processes and there is no difference. On the other hand, it can be seen in Table 4 that the technostress level is affected by the education process $(F(3-144)=3.603, p<.05)$. Technostress levels of teacher candidates differ in terms of educational processes. According to the results of the Scheffe test, one of the Post-Hoc tests performed to determine the difference, it is seen that the technostress levels of the $1^{\text {st }}$ grades $(X=3,73)$ are significantly higher than the $4^{\text {th }}$ grades $(X=3,21)$. In this respect, it can be said that the technostress levels of teacher candidates decreased after the education process.

\section{Attitudes towards Technology and Technostress Levels of Geography Teacher Candidates According to Daily Average Internet Usage Times}

In line with the sub-goals, technostress levels and attitudes towards technology of geography teacher candidates according to the average daily internet usage time were examined, and the results of the findings are given in Table 5. 
Table 5: Comparison of Technology Attitude and Technostress Levels According to Average Daily Internet Usage Time

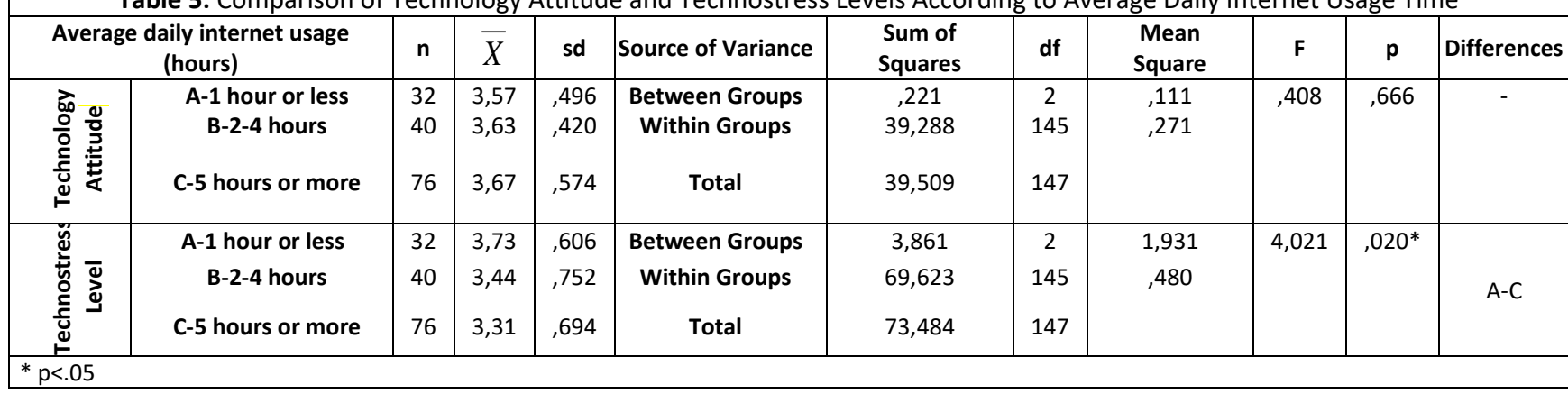

When Table 5 is examined, it can be said that geography teacher candidates' attitudes towards technology do not differ in terms of daily internet usage duration $(F(2-145)=0.408, p>.05)$. On the other hand, the average daily internet usage is a variable that causes differentiation in technostress levels of geography teacher candidates $\left(F_{(2-145)}=4.021, p<.05\right)$. As a result of the comparison test made to determine the difference, it was observed that the technostress level of the geography teacher candidates who use the internet for an average of 1 hour and less per day $(X=3,73)$ is higher than the technostress level of those who use the internet for 5 hours or more $(X=3,31)$.

\section{Attitudes towards Technology and Technostress Levels of Geography Teacher Candidates by Gender}

In line with another sub-purpose, teacher candidates' attitudes towards technology and their technostress levels were compared according to their gender, and the results are given in Table 6.

\begin{tabular}{|c|c|c|c|c|c|c|c|}
\hline & Gender & $\mathbf{n}$ & $\bar{X}$ & sd & df & $\mathbf{t}$ & $\mathbf{p}$ \\
\hline Attitude towards Technology & $\begin{array}{c}\text { Female } \\
\text { Male }\end{array}$ & $\begin{array}{l}79 \\
69 \\
\end{array}$ & $\begin{array}{l}3,53 \\
3,76 \\
\end{array}$ & $\begin{array}{l}, 452 \\
, 563 \\
\end{array}$ & 146 & $-2,748$ & ,008* \\
\hline Technostress Level & $\begin{array}{c}\text { Female } \\
\text { Male }\end{array}$ & $\begin{array}{l}79 \\
69 \\
\end{array}$ & $\begin{array}{l}3,52 \\
3,35 \\
\end{array}$ & $\begin{array}{l}609 \\
, 799 \\
\end{array}$ & 146 & 1,450 & 149 \\
\hline \multicolumn{8}{|c|}{$* \mathrm{p}<.05$} \\
\hline
\end{tabular}

Table 6 shows that while geography teacher candidates' attitudes towards technology differ according to gender $\left[t_{(146)}=-2.748, p<.05\right]$, it shows that gender is not a significant source of difference in terms of technostress levels [ $t_{(146)}=-$ $1.450, p>.05]$. Accordingly, in terms of attitude towards technology, male $(X=3,76)$ have more attitudes towards technology than female $(X=3,53)$. However, in terms of technostress, the difference between the technostress levels of male $(X=3,35)$ and female $(X=3,52)$ geography teacher candidates is not statistically significant. In other words, the technostress levels of female and male geography teacher candidates are the same.

\section{The Relationship between Geography Teacher Candidates' Attitudes towards Technology and Technostress Levels}

Finally, the relationship between the attitudes of geography teacher candidates towards technology and technostress was examined. The results obtained are given in Table 7.

\begin{tabular}{|c|c|c|}
\hline & & Technostress Leve \\
\hline Attitudes towards Technology & $\begin{array}{c}\text { Pearson correlation }(r) \\
p \\
N\end{array}$ & $\begin{array}{c}-0,217 \\
0,00^{* *} \\
148\end{array}$ \\
\hline$* * p<.01$ & & \\
\hline
\end{tabular}

When Table 7 is examined, it is seen that there is a negative and low-level relationship between geography teacher candidates' attitudes towards technology and their technostress levels $(r=-.217, p<.01)$. The correlation coefficient takes values between 0 and $+(-)$. If this coefficient approaches +1 , it is determined that there is a strong direct relationship between the variables, and if it approaches -1 , there is a strong inverse relationship between the variables. The correlation coefficient with a value of 0 indicates that there is no relationship between the variables (Ratner, 2009). The -.217 correlation value obtained in the study shows that there is an inverse and low-level relationship. In this respect, it can be interpreted that the increase in the attitudes of pre-service geography teachers towards technology 
will reduce their technostress levels partially or slightly. As the teacher candidates' attitudes towards technology increase, their technostress levels decrease slightly. However, this reduction can explain only $4.7 \%$ of the total variance.

\section{CONCLUSION AND DISCUSSION}

Especially with the Covid-19 global epidemic, the use of technology in education processes has caused intense pressure. Indeed, Penado Abilleira et al. (2021) stated that teachers' technostress levels increased during the Covid-19 epidemic. In this study, it was thought that teacher candidates were also affected by this pressure, and the following results were obtained by collecting data from 148 pre-service teachers studying in geography education departments by considering their attitudes towards technology use and their technostress levels.

Geography teacher candidates' attitudes towards technology and technostress levels were found to be medium level (Table 3). Similar results were obtained in researches on the attitudes of pre-service teachers towards technology (Ipek and Acuner, 2011; Özgür et al., 2015; Şahin and Namlı, 2019). In some studies investigating the technostress levels of teachers, it is stated that technostress is at a medium level. While Lee (2018) expressed the technostress levels of teachers as medium level, he stated that there is a significant relationship between coping with technostress and teacher profession competence. Coklar et al. (2016), as a result of his research with teachers, found that their technostress level is medium. In terms of sub-dimensions of technostress, teachers' technical issue oriented and social oriented technostress levels are high; stated the learning teaching process oriented, professional oriented and personal oriented technostress levels as medium level. Al-Fudail and Mellar (2008) stated that teachers experience technostress in certain subjects while using technology in the classroom. Al-Fudail and Mellar (2008) stated that technostress levels of teachers are affected by factors such as the educational environment, teachers' skills, and their facilities. The experiences of geography teacher candidates in educational processes and their current opportunities can be shown as important factors affecting the result obtained for technostress. On the other hand, Li and Wang (2021) state that experience is an important factor that reduces technostress. In this respect, the fact that participants' teaching processes are measured as well as their technology use skills may have caused teacher candidates' technostress levels to be at a medium level and differentiation in sub-dimensions. Hew and Brush (2007) stated that three factors are important for the integration of technology into education: teachers' technology skills, their beliefs about technology, and perceived technology barriers. In this respect, it can be stated that teacher candidates of medium level attitude and technostress need support for technology integration into educational processes.

The attitudes of geography teacher candidates towards technology do not differ according to their grades (Table 4). In terms of technostress level, 1st grade students experience more technostress than 4th grade students. While Dargut and Çelik (2014) stated that the attitudes of pre-service teachers did not differ according to the grade, Şahin and Namlı (2019) stated that senior teacher candidates have more attitudes towards using technology in education than the preservice teachers studying in the first grade. No research has been found on teacher candidates in terms of technostress. However, in studies conducted with educators in different institutions, it is stated that the experience of using technology reduces technostress (Lee, 2018; Li and Wang, 2021; Penado Abilleira, et al., 2021; Syvänen, et al., 2016). In addition to information technologies and instructional technologies and material development courses in education faculties, it can be said that taking teaching profession knowledge courses and teaching practice experience training for items in the technostress scale has an effect on the decrease of technostress. Similarly, teacher candidates' use of technology in many courses reveals an increase in their positive attitude towards technology. As a matter of fact, it is seen in the literature that the experience of using technology increases with the experience of using technology depending on the grade level and experience of education (Gülseçen and Kubat, 2006; Shapka and Ferrari, 2003; Zhang and Martinovic, 2008). King and He (2006) express the importance of task-technology compatibility in technology integration. In this respect, the fact that the effect of the education process and the experience does not cause any difference in attitude can be interpreted as the use of technology less in the trainings in the geography department. Menzi, Çalışkan and Çetin (2012) lower technology use competence of teacher candidates studying in verbal departments also supports this interpretation.

While gender is an important variable for attitude towards technology, the level of technostress is not affected by gender. In terms of attitude, males have a higher attitude than females (Table 6). This finding is similar to the results of the research conducted by Özdemir and İmra (2017) and İpek and Acuner (2011). However, there are different results with the result of the research that the technology attitude does not differ according to gender. Sang et al. (2010) emphasizes that attitude is not affected by gender as a factor affecting Information and Communication Technology (ICT) integration. This finding may have resulted from the characteristics and cultural perception of Geography teacher candidates, which is the practice group. Baştürk Akca and Kaya (2016) state that the difference in gender perception can be an important parameter affecting the digital divide as a concept that guides the use of technology. In other 
words, the fact that the opportunities and opportunities offered to women and men in the society are in favor of men may have increased their attitudes towards technology. On the other hand, when examined in terms of technostress, it was seen that there was no difference in attitude (Table 6). In this respect, the fact that the use of digital technology, which previously required more technical skills requires less technical skills with opportunities such as social media, internet tools, mobile technologies, has paved the way for females to be more competent than males in using technology in certain subjects and reduced the gender effect in the digital divide (Bode, 2017). The World Economic Forum (WEF) stated in the report published in 2020 that the digital divide between women and men has been closed with the increase in the accessibility of digital technologies in recent years (WEF, 2020). Similarly, Arif, Walayat and Atiq (2011) stated that women in most developing and developing countries now have access to more technology and they now have significant gains. The fact that the technostress level was not different according to gender within the scope of the study may be due to their recent training on the same technologies and their similar use in their educational processes. Wilkes, Guppy, and Farris (2008) stated that changing attitudes takes time. In this respect, it can be said that the difference in attitude towards technology will disappear in time within the framework of the opportunities provided.

A negative and low-level relationship was found between the geography teacher candidates' attitudes towards technology and their technostress levels (Table 7). Syvänen and colleagues (2016) stated that there is a relationship between attitude towards ICT use and technostress level. Usta and Korkmaz (2010) state that there is a relationship between pre-service teachers' attitudes towards technology use and their competencies in technology use. Similarly, the decrease in technostress according to the duration of internet usage, which is one of the research results, also confirms this result. Again, in different sources (Lee, 2018; Li and Wang, 2021; Penado Abilleira, et al., 2021; Syvänen, 2016) it is stated that technology use competence (experience, opportunity, attitude, etc.) are factors that reduce technostress. In this respect, it may be considered natural that there is a low-level relationship between technostress and technostress, which handles the use of technology with one dimension.

\section{SUGGESTIONS}

Within the scope of the research, the technology and technostress levels of geography teacher candidates were investigated. It is stated in the literature that there will be differences in the verbal and quantitative departments. In this respect, a new research can be designed for sections with different characteristics. In addition, the scale used to measure attitude towards technology is expressed as a "general technology scale" by Aydın and Kara (2013). In line with the experience gained, it may be suggested to conduct a research with an attitude scale towards digital-oriented information and communication technologies. It may also be suggested to provide geography teacher candidates with more applied training in order to gain an attitude towards technology and reduce their technostress'.

\section{References}

Agar, J. (2020). What is technology?, Annals of Science, 77(3), 377-382. Doi: 10.1080/00033790.2019.1672788

Ajzen, I. (1991). The theory of planned behavior. Organizational Behavior and Human Decision Processes, 50(2), $179-211$.

Al-Fudail, M. \& Mellar, H. (2008). Investigating teacher stress when using technology. Computers \& Education, 51(3), 1103-1110. Doi: 10.1016/j.compedu.2007.11.004

Arif, A., Walayat, H. \& Atiq, A. (2011). E-learning: closing the digital gap between developed and developing countries. Australian Journal of Basic and Applied Sciences, 5(11), 903-908.

Aydın, F. \& Kara, F. N. (2013). Öğretmen adaylarının teknolojiye yönelik tutumları: ölçek geliştirme çalışması. Journal of Turkish Science Education, 10(4), 103-118.

Baştürk Akca, E. \& Kaya, B. (2016). Toplumsal cinsiyet eşitliği perspektifinden dijital bölünme ve farklı yaklaşımlar. Intermedia International e-Journal, 3(5), 301-319. Doi: 10.21645/intermedia.2017.16

Bauer, J. \& Kenton, J. (2005). Toward technology integration in the schools: why it isn't happening. Journal of Technology and Teacher Education, 13(4), 519-546.

Bode, L. (2017). Closing the gap: gender parity in political engagement on social media. Information, Communication \& Society, 20(4), 587-603. Doi: 10.1080/1369118X.2016.1202302

Brillhart, P. E. (2004). Technostress in the workplace: managing stress in the electronic workplace. Journal of American Academy of Business, 5(1/2), 302-307.

Brod, C. (1984). Technostress: The Human Cost of The Computer Revolution. Reading, Mass.: Addison-Wesley.

Çetin, i. (2012). Tutum nedir? Tutumların özellikleri. 23 Nisan 2021 tarihinde https://www.tavsiyeediyorum.com /makale_9597.htm adresinden edinilmiştir. 
Champion, S. (1988). Technostress: technology's toll. School Library Journal, 35(3), 48-51.

Chase, Z. \& Laufenberg, D. (2011). Embracing the squishiness of digital literacy. Journal of Adolescent \& Adult Literacy, 54(7), 535537. doi:10.1598/JAAL.54.7.7

Chen, C. H. (2008). Why do teachers not practice what they believe regarding technology integration?. The Journal of Educational Research, 102(1), 65-75. Doi: 10.3200/JOER.102.1.65-75

Çoklar, A. N., Efilti, E. \& Sahin, L. (2017). Defining teachers' technostress levels: a scale development. Journal of Education and Practice, 8(21), 28-41.

Çoklar, A. N., Efilti, E., Sahin, L. \& Akçay, A. (2016). Investigation of techno-stress levels Of teachers who were included ın technology Integration processes. Turkish Online Journal of Educational Technology, Special Issue for INTE 2016, 1331-1339.

Creswell, J. W. (2012). Educational Research: Planning, Conducting, and Evaluating Quantitative and Qualitative Research (4th ed.). Boston, MA: Pearson Education, Inc.

Dalal, M., Archambault, L. \& Shelton, C. (2017). Professional development for international teachers: examining TPACK and technology integration decision making. Journal of Research on Technology in Education, 49(3-4), 117-133. Doi: 10.1080/15391523.2017.1314780

Dargut, T. \& Çelik, G. (2014). Türkçe öğretmeni adaylarının eğitimde teknoloji kullanımına ilişkin tutum ve düşünceleri. Ana Dili Eğitimi Dergisi, 2(2), 28-41.

Davis, F. D. (1989). Perceived usefulness, perceived ease of use, and user acceptance of information technology. MIS Quarterly, 13(3), 319-340.

Demirci, A., Taş, H. i. \& Özel, A. (2007). Türkiye'de ortaöğretim coğrafya derslerinde teknoloji kullanımı. Marmara Coğrafya Dergisi, 15, 37-54.

Doğru, E. \& Aydın, F. (2018). Coğrafya öğretmenlerinin teknolojik pedagojik alan bilgisi (TPAB) hakkındaki düşünceleri ve bunu kullanma durumları. Eğitim Kuram ve Uygulama Araştırmaları Dergisi, 4(2), 88-100.

Eagly, A. H. \& Chaiken, S. (1998). Attitude structure and function. In D. T. Gilbert, S. T. Fiske \& G. Lindzey (Eds.), Handbook of social psychology (pp. 269-322). New York: McGraw-Hill.

Erten, S. (2002). Planlanmış davranış teorisi ile uygulamalı öğretim metodu. Hacettepe Üniversitesi Edebiyat Fakültesi Dergisi, 19(2).217-233.

Ertmer, P.A. (2005). Teacher pedagogical beliefs: the final frontier in our quest for technology integration? Educational Technology Research and Development, 53(4), 25-39.

Gülseçen, S. \& Kubat, A. (2006). Teaching ICT to teacher candidates using PBL: a qualitative and quantitative evaluation. Journal of Educational Technology \& Society, 9(2), 96-106.

Hew, K. F. \& Brush, T. (2007). Integrating technology into K-12 teaching and learning: current knowledge gaps and recommendations for future research. Educational Technology Research and Development, 55(3), 223-252.Doi: 10.1007/s11423-006-9022-5

İpek, C. \& Acuner, H. Y. (2011). Sınıf öğretmeni adaylarının bilgisayar öz-yeterlilik inançları ve eğitim teknolojilerine yönelik tutumları. Ahi Evran Üniversitesi Kırşehir Eğitim Fakültesi Dergisi, 12(2), 23-40.

Karasar, N. (2012). Bilimsel Arastirma Yöntemleri. Ankara: Nobel Yayıncllık.

Kim, C., Kim, M. K., Lee, C., Spector, J. M. \& DeMeester, K. (2013). Teacher beliefs and technology integration. Teaching and Teacher Education, 29, 76-85. Doi: 10.1016/j.compedu.2012.02.001

King, W. R. \& He, J. (2006). A meta-analysis of the technology acceptance model. Information \& management, 43(6), 740-755. Doi: 10.1016/j.im.2006.05.003

Lawless, K. A. \& Pellegrino, J. W. (2007). Professional development in integrating technology into teaching and learning: knowns, unknowns, and ways to pursue better questions and answers. Review of Educational Research, 77(4), 575-614. Doi: 10.3102/0034654307309921

Lee, J. Y. (2018). Mediating effect of stress coping in the relationship between technostress and teacher efficacy of early childhood teachers. Korean Journal of Stress Research, 26(1), 46-51. Doi: 10.17547/kjsr.2018.26.1.46

Li, L. \& Wang, X. (2021). Technostress inhibitors and creators and their impacts on university teachers' work performance in higher education. Cognition, Technology \& Work, 23(2),315-330.

Marinoni, G., Van't Land, H. \& Jensen, T. (2020). The impact of Covid-19 on higher education around the world. IAU Global Survey Report. 23 Nisan 2021 tarihinde https://www.iau-aiu.net/IMG/pdf/iau_covid19_and_he_survey_report_final_may_2020.pdf adresinden edinilmiştir.

McCarthy, J. \& Wright, P. (2004). Technology as experience. Interactions, 11(5), 42-43. Doi: 10.1145/1015530.1015549

Menzi, N., Çalışkan, E. \& Çetin, O. (2012). Öğretmen adaylarının teknoloji yeterliliklerinin çeşitli değişkenler açısından incelenmesi. Anadolu Journal of Educational Sciences International, 2(1), 1-18.

Mercan, N. (2015). Ajzen'in planlanmiş davraniş teorisi bağlaminda whistleblowing (bilgi ifşasi). Sosyal ve Beşeri Bilimler Dergisi, 7(2), 1-14.

Özdemir, U. \& İmra, T. A. Ç. (2017). Sını öğretmeni adaylarının teknolojiye yönelik tutumlarının belirlenmesi. Uluslararası Temel Eğitim Araştırmaları Dergisi, 1(1), 1-7. 
Özgür, Ö., Orhan, D., Dönmez, P. \& Kurt, A. A. (2015). Öğretmen adaylarının bireysel yenilikçilik profilleri ve teknoloji tutum düzeyleri arasındaki ilişkinin incelenmesi. Trakya Üniversitesi Eğitim Fakültesi Dergisi, 5(1), 65-76.

Penado Abilleira, M., Rodicio García, M. L., Ríos-de Deus, M. P. \& Mosquera González, M. J. (2021). Technostress in Spanish university teachers during the COVID-19 Pandemic. Frontiers in Psychology, 12, 1-11. Doi: 10.3389/fpsyg.2021.617650

Ratner, B. (2009). The correlation coefficient: Its values range between+1/- 1, or do they?. Journal of Targeting, Measurement and Analysis for Marketing, 17(2), 139-142. Doi: 10.1057/jt.2009.5

Şahin, M. C. \& Namlı, N. A. (2019). Öğretmen adaylarının eğitimde teknoloji kullanma tutumlarının incelenmesi. Türkiye Sosyal Araştırmalar Dergisi, 23(1), 95-112.

Sang, G., Valcke, M., Van Braak, J. \& Tondeur, J. (2010). Student teachers' thinking processes and ICT integration: predictors of prospective teaching behaviors with educational technology. Computers \& Education, 54(1), 103-112. Doi: 10.1016/j.compedu.2009.07.010

Şendurur, P. \& Arslan, S. (2017). Eğitimde teknoloji entegrasyonunu etkileyen faktörlerdeki değişim. Mehmet Akif Ersoy Üniversitesi Eğitim Fakültesi Dergisi, 43, 25-50.

Shapka, J. D. \& Ferrari, M. (2003). Computer-related attitudes and actions of teacher candidates. Computers in Human Behavior, 19(3), 319-334. Doi: 10.1016/S0747-5632(02)00059-6

Shattuck, G. (2010). Understanding school leaders' role in teachers' adoption of technology integration classroom practices. In Educational media and technology yearbook (pp. 7-28). Boston, MA: Springer.

Syvänen, A., Mäkiniemi, J. P., Syrjä, S., Heikkilä Tammi, K. \& Viteli, J. (2016). When does the educational use of ICT become a source of technostress for Finnish teachers?. In Seminar. 20 Nisan 2021 tarihinde https://journals.os/omet.no/index.php/seminar/article/view/2281 adresinden edinilmiştir.

Tatlı, Z. \& Akbulut, H. í. (2017). Öğretmen adaylarının alanda teknoloji kullanımına yönelik yeterlilikleri. Ege Eğitim Dergisi, 18(1), 3155.

Topsakal, S. (2006). ilköğretim 6.,7. ve 8. Sınıflar Fen ve Teknoloji Öğretimi. Ankara: Nobel Yayıncılık.

Usta, E. \& Korkmaz, Ö. (2010). Öğretmen adaylarının bilgisayar yeterlikleri ve teknoloji kullanımına ilişkin algıları ile öğretmenlik mesleğine yönelik tutumları. Uluslararası Insan Bilimleri Dergisi, 7(1), 1335-1349.

Wang, K., Shu, Q. \& Tu, Q. (2008). Technostress under different organizational environments: an empirical investigation. Computers in Human Behavior, 24(6), 3002-3013. Doi: 10.1016/j.chb.2008.05.007

WEF- World Economic Forum, (2020). Global gender gap report-2020. 2 Mayı 2021 tarihinde http://www3.weforum.org/docs/WEF_GGGR_2020.pdf adresinden edinilmiştir.

Weil, M. M. \& Rosen, L. D. (1997). Technostress: Coping with technology@work@ home@ play (Vol. 13, p. 240). New York: J.Wiley.

Wilkes, R., Guppy, N. \& Farris, L. (2008). No Thanks, We're Full: Individual Characteristics, National Context, and Changing Attitudes toward Immigration. International Migration Review, 42(2), 302-329. Doi: 10.1111/j.1747-7379.2008.00126.x

Zhang, Z. \& Martinovic, D. (2008). ICT in teacher education: examining needs, expectations and attitudes. The Canadian Journal of Learning and Technology, 34(2), 149-166. 